\section{Degradative Pathway of L-Leucine in Proteus vulgaris}

IT was reported by Coon et al. ${ }^{1-4}$ that in the metabolic pathway of L-leucine, isovaleryl coenzyme $A$ was formed from $\alpha$-ketoisocaproic acid, a deaminated product of leucine, in the presence of coenzyme $A$ (Co $A$ ), etc. I postulate that this reaction involves the following two steps :

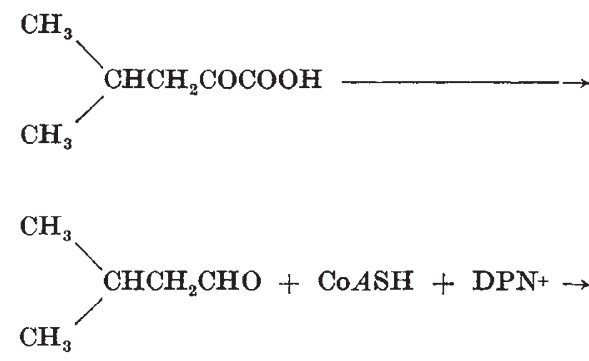

In this communication it is reported that a cell-free extract which catalyses the reaction (1) was obtained from Proteus vulgaris.

Proteus vulgaris was cultivated at $37^{\circ} \mathrm{C}$. for $18 \mathrm{hr}$. on peptone-broth agar slant. The cells were harvosted, washed three times with de-ionized water, and suspended in $2 \times 10^{-2} M$ phosphate buffer, $p \mathrm{H} 7 \cdot 2$. The washed cell suspension was disrupted by sonic oscilla tion in a Kubota vibrator, $10 \mathrm{kc} . / \mathrm{s}$., for $10 \mathrm{~min}$. After centrifugation the supernatant was made 100 per cent saturated with respect to ammonium sulphate. The precipitate was dialysed against running water. In some cases, this dialysed protein solution was further fractionated with ammonium sulphate or cold acetone.

$\alpha$-Ketoisocaproic acid, used in the experiments, was prepared by extracting with acidic ether from the reaction mixture in which $\mathrm{L}$-leucine was deaminated oxidatively by $P$. vulgaris. The melting point of the 2,4-dinitrophenylhydrazone of this keto-acid was $140-143^{\circ} \mathrm{C}$. In this ether extract no other compound was detected by paper chromatography.

Carbon dioxide output was determined by the conventional Warburg method. The reaction mixture consisted of the following in a final volume of 2.5 ml. : $1.67 \times 10^{-1} M$ acetate buffer at $p \mathrm{H} 5 \cdot 0,0 \cdot 5 \mathrm{ml}$.; $5 \times 10^{-3} M$ magnesium sulphate, $0.25 \mathrm{ml}$; $2 \times$ $10^{-1} M$ a-ketoisocaproate, $0.125 \mathrm{ml}$; and enzyme, $1 \mathrm{mgm}$. protein. This reaction was carried out at $30^{\circ} \mathrm{C}$. for $10 \mathrm{~min}$.

The reaction of decarboxylation proceeded in nitrogen gas as well as in air $\left(Q_{\mathrm{CO}_{2}}^{\mathrm{N}_{2}}\right.$ and $Q_{\mathrm{CO}}^{\mathrm{Air}}$ values were 1,158 and 1,207 , respectively). The optimal $p \mathrm{H}$ was $5 \cdot 0$, and optimal substrate concentration was found to be $1 \times 10^{-2} M$; half maximal activity was obtained with $1.5 \times 10^{-3} M$. Though it is not yet clear whether the reaction requires co-factors, coenzyme $A$, adenosine triphosphate, diphosphothiamine and $\mathrm{Mg}^{2+}$ were not required in the case of this crude enzyme.

Moreover, the reaction products were identified with paper chromatography. Three reaction systems were made as follows: (a) complete system (same as above experiments) ; (b) control system in which the enzyme was omitted; and (c) control system in which the substrate was omitted. The volume of each reaction mixture was $10 \mathrm{ml}$. Immediately after incubation for $40 \mathrm{~min}$. at $30^{\circ} \mathrm{C} ., 0.5 \mathrm{ml}$. of mercuric acetate $\left(5 \times 10^{-1} M\right)$ was dropped in the reaction mixture. After the precipitate was discarded, 2,4-dinitrophenylhydrazine solution was added and stored at room temperature overnight. 2,4-Dinitrophenylhydrazone formed was washed thoroughly with hydrochloric acid, and dissolved with ether. The ether solution was used for paper chromatography. In experiment $c$ no precipitate was formed. 2,4-<smiles>CC(C)CC=O</smiles><smiles>CC(C)CC(=O)OC=PN</smiles>

Dinitrophenylhydrazone formed from experiments $a$ and $b$ and isovaleroaldehyde solution were developed with phenol (with 20 per cent water), isoamyl alcohol, and $n$-propyl alcohol as solvent, respectively. The results were represented in Table 1.

Table 1

\begin{tabular}{|c|c|c|c|}
\hline \multirow[b]{2}{*}{ Solvent } & \multicolumn{3}{|c|}{$R_{F}$ value } \\
\hline & Exp. $a$ & Exp. $b$ & $\begin{array}{l}\text { Hydrazone of iso- } \\
\text { valeroaldehyde }\end{array}$ \\
\hline $\begin{array}{l}\text { Phenol } \\
\text { Isoamyl alcohol } \\
n \text {-Propyl alcohol }\end{array}$ & $\begin{array}{l}1 \cdot 00 \\
0 \cdot 92 \\
0 \cdot 91\end{array}$ & $\begin{array}{c}0.81 \\
0.83 \\
0.82 \sim 0.73\end{array}$ & $\begin{array}{l}1 \cdot 00 \\
0 \cdot 92 \\
0 \cdot 94\end{array}$ \\
\hline
\end{tabular}

As shown in Table 1, one spot was obtained in experiment $a$, and the spot had the same $R_{F}$ value of the hydrazone of isovaleroaldehyde. Furthermore, these spots were eluted from the paper with 15 per cent potassium hydroxide solution and were examined spectrophotometrically. It was concluded that isovaleroaldehyde was formed from this reaction system. The results reported in this communication and other experiments in which $\alpha$-ketoisocaproate was oxidized after vigorous decarboxylation, and reduced 2,6-dichlorophenolindophenol or methylene blue by this enzyme system in the presence of coenzyme $A$ (and adenosine triphosphate and diphosphopyridine nucleotide), indicate that $\alpha$-ketoisocaproate was metabolized via isovaleroaldehyde (reaction (1)), and probably via reaction (2). Attempts at solving the latter reaction are in progress. Further details of this work will be published elsewhere.

I wish to thank Prof. S. Usami for his advice throughout the progress of this work.

Department of Botany, SHOJI SASAKI Faculty of Science,

Hokkaido University, Sapporo, Japan.

${ }^{1}$ Bachhawat, B. K., Robinson, W. G., and Coon, M. J., J. Amer. Chem. Soc. $76,3098(1954)$.

${ }^{2}$ Coon, M. J., Fed. Proc., 14, 762 (1955).

'Coon, M. J., Robinson, W. G., and Bachhawat, B. K., "Amino Acid Metabolism", 431 (Baltimore, 1955).

${ }^{4}$ Bachhawat, B. K., Woessner, jun., J. F., and Coon, M. J., Fed. Proc., $15,214(1956)$. 